\title{
WFDC1 wt Allele
}

National Cancer Institute

\section{Source}

National Cancer Institute. WFDC1 wt Allele. NCI Thesaurus. Code C51413.

Human WFDC1 wild-type allele is located in the vicinity of $16 \mathrm{q} 24.3$ and is approximately $35 \mathrm{~kb}$ in length. This allele, which encodes WAP four-disulfide core domain protein 1, plays a role in the negative regulation of cell growth. WFDC1 gene expression is downregulated in certain cancers such as prostate cancer. 